\title{
WATER POWER GENERATOR FOR PUBLIC ROAD ILLUMINATION LIGHTS OF PADI VILLAGE MOJOKERTO
}

\author{
Rohib Ilma Suktawan*, Akhmad Solikin \\ Department of Electrical Engineering, \\ Faculty of Engineering, University of PGRI Adi Buana Surabaya \\ *Corresponding Email address: rohib.ilman04@gmail.com
}

\begin{abstract}
Electricity problems in rural areas more and more electric power is needed. Until now, power plants that use water turbines are environmentally friendly electricity producers, so the potential for energy from the air needs to be utilized to address the demand for electricity. Therefore, the solution to this problem is to use the "Design and Construction of Hydroelectric Generator for Public Street Lighting".

The generator is a source of electric voltage obtained by converting mechanical energy into electrical energy.
\end{abstract}

\section{INTRODUCTION}

Electricity is an important part of the ongoing human life today. But over time, more and more electric power is needed. Until now, power plants that use water turbines are environmentally friendly electricity producers, so the potential energy from water needs to be utilized to overcome the large demand for electricity. Hydroelectric power is one of the few renewable energies capable of developing and will become a major source of energy in the future. The generator of hydroelectric power was first used in Indonesia since 1882 to drive water turbines as a supplier for industrial electricity needs and lighting in villages where water potential can be utilized (Sentanu, 2013).

An impulse turbine is a turbine whose working system utilizes all water energy in the form of speed, pressure and potential energy into kinetic energy that rotates the turbine so that causes the mechanical energy on the shaft to be transmitted to the generator to become electricity. The impulse turbine has the same pressure at
The generator works based on the principle of electromagnetic induction, which is by rotating a coil in a magnetic field so that the induced GGL (Electric Motion Force) arises. In this thesis, a research is conducted on the Water Turbine Generator in the river in the village area of Padi Gondang Mojokerto as an object of water flow in order to generate electric power to reduce crime in the area in the form of a load object in the form of Public Street Lighting.

Keywords: Generator, Public Road Illumination Lights, Rural.

each blade of motion (runner). The way an impulse turbine works is to convert potential energy into kinetic energy at the nozzle. The water that comes out of the nozzle at a high speed will hit the turbine blade which causes the direction of the flow velocity to change so that there is a change in momentum (impulse) so that the turbine wheel will rotate. Examples of impulse turbines are platoon, turgo, and crossflow turbines.

In mountainous areas there are still many small rivers whose water discharge can be used for road lighting in low-water areas which are minimal at night. From the above problem, the writer wants to take advantage of the existing water currents in Padi Village, Gondang District, Mojokerto Regency because there is still a lack of public street lighting, therefore I take advantage of the existing river flow as a small-scale power plant used for Public Street Lighting (PJU) lights with power. 20 watts with the help of "Design and Build a Hydro electric Generator." 


\section{METHOD}

In principle, hydropower plants use different heights and the amount of water discharge per second that exists in irrigation water flows, rivers or waterfalls.
This water flow will rotate the turbine shaft so that it produces mechanical energy. This energy then drives the generator and produces electrical energy.

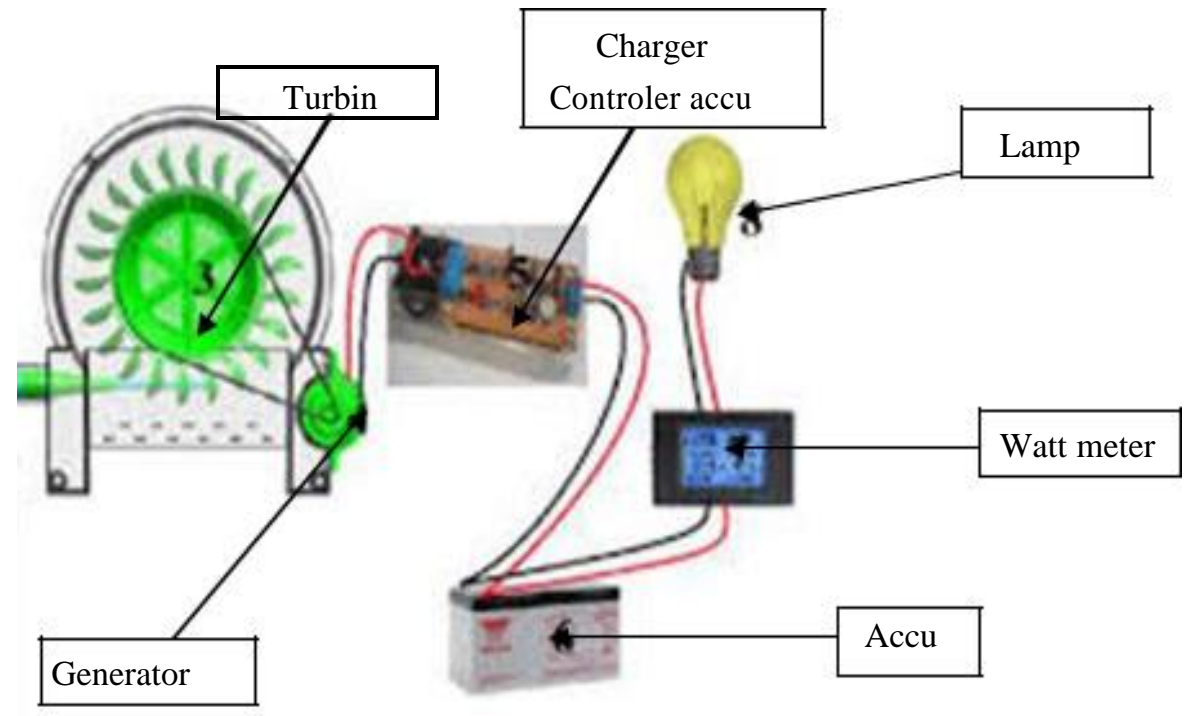

Figure 2.1 Design.

The materials and equipment used in Titsedaidfereatscharequipment used in this

a. Arduino Uno is used to program water discharge data

b. Water Flowmeter Sensor is used to measure the amount or flow rate of water from a fluid flowing in a pipe or open connection.

c. A digital multimeter that is used to measure voltage and power.

d. A digital multimeter that is used to measure voltage and power.

A generator driven by a water turbine. Where the turbine itself functions to drive the turbine which is driven by the flow of river water so that it rotates a coil in a magnetic field so that the induced GGL (Electric Motion Force) arises. From this function, you can use GGL (Electric Motion) induction to turn on the PJU.

The test steps carried out to observe the effect of rotational speed and load on the DC generator output are as follows.

a. Generator material testing, ensuring generator material performance is working properly.

b. Water discharge testing per second.

c. Turbine load test. d. Testing the power generated by the generator.

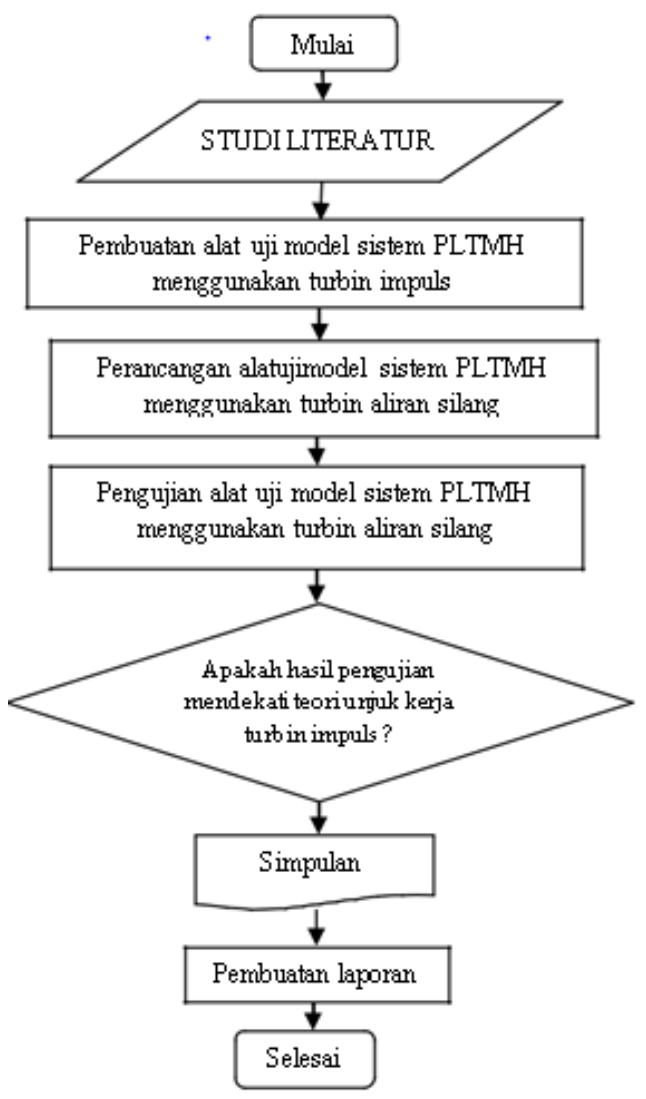

Figure 2.2 System test flowchart 
A variable is something that differentiates or changes the value. Values can be different at different times for the same object or person, or other values can be different at the same time for different objects or people. In this study the independent variables and the dependent variable are:

a. The independent variables are: Water discharge Variable Operational Definition: In this case the water discharge can affect the flow of water to rotate the turbine shaft so as to produce mechanical energy. This energy then drives the generator and produces electrical energy.

b. The dependent variables are:

1. Measuring the water discharge and the value of the voltage generated by the generator.

2. Measure the energy generated by the generator in 1 day.

This study uses the method of observation and documentation, namely to observe the test results and study references related to the design of the tool.

\section{RESULT AND DISCUSSION}

This chapter will discuss the experiments that have been carried out. Researchers carry out experimental tools and observation tools so that researchers can analyze the experiment. Testing is carried out in several stages, including testing a series of tools and tool components and testing the application program that has been made. This test aims to determine the results of the design of the tools that have been made. From this test will be analyzed by the researcher. After further analysis, a discussion of the performance and success of the design of a hydropower generator for public street lighting (pju) was conducted.

This chapter will discuss the testing and analysis of the data testing tools from the design results of the MHPP with impulse turbines using permanent magnet DC that have been made. Testing of this tool is intended to ensure that the equipment can function properly. Testing of this tool includes testing the
Microcontroller output voltage, testing the flow water sensor, measuring the water discharge, testing the whole system. After carrying out several tool tests, the data obtained will be analyzed to determine the work process of the entire tool system being made.

\subsection{Presentation of Microcontroller Output Voltage Testing Data.}

The microcontroller used in this final project is to use Uno (Arduino Uno R3). To find out that the microcontroller can be used and the voltage issued is according to the datasheet, it is necessary to measure the microcontroller output voltage by measuring the voltage on each pin on the Arduino Uno R3. The program is uploaded via glossop to Arduino Uno R3. Measure on each pin of the Arduino board in a state of high voltage and low voltage. The input voltage used comes from a laptop USB of +5 volts.

\subsection{Water Flow Sensor Testing.}

Flow water sensor testing is carried out to retrieve flow velocity data read by the sensor. Sensor testing is carried out by flowing water into the hole in the sensor. Next perform the calibration by changing the unit liter / second to meter / second.

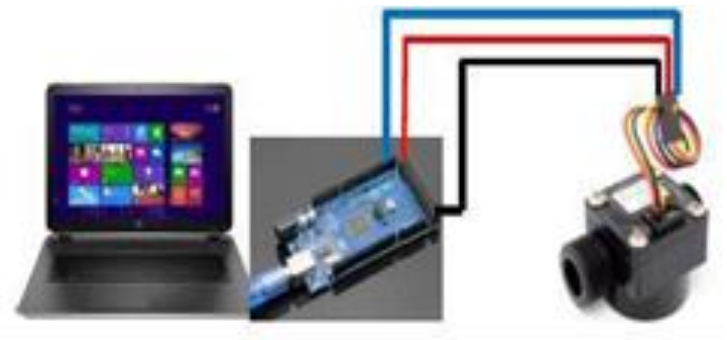

Figure 2.2 Flow Water Sensor Testing Series

\subsection{Overall Testing}

Overall testing of the components of the tool is carried out so that everything runs well when used in actual conditions by combining all LCD components and programs, water level sensors, water pumps, to the Arduino Uno microcontroller. For testing the tool used the following circuit: 
BEST

Journal of Applied Electrical \& Science Technology - University of PGRI Adi Buana

p-ISSN 2715-2871

e-ISSN 2714-5247

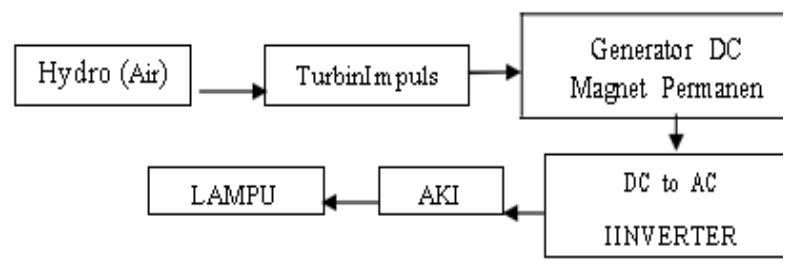

Figure 2.3 Overall Test Series

Based on the data obtained in this study, data analysis was carried out in stages and was careful and thorough. By analyzing the data obtained, this results in the following:

1. Test whether the Arduino Uno microcontroller when programmed can receive information from the Water level sensor and send information to the LCD.

2. Test whether the sensor is working properly by connecting the $\mathrm{v}+$ and $\mathrm{v}$ to the Arduino Uno port and the water level sensor.

3. Test whether the output of the water turbine generator works properly by connecting it to Arduino so that it will automatically turn on.

4. Test whether the LCD and sensor function properly or not.

5. Test as a whole each component part is working properly.

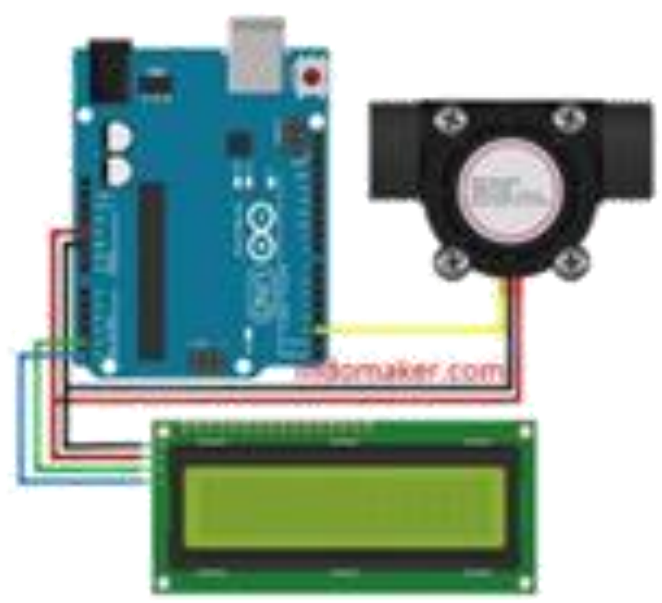

Figure 2.4 Series of Flow Meters on a $16 \times$ 2 LCD

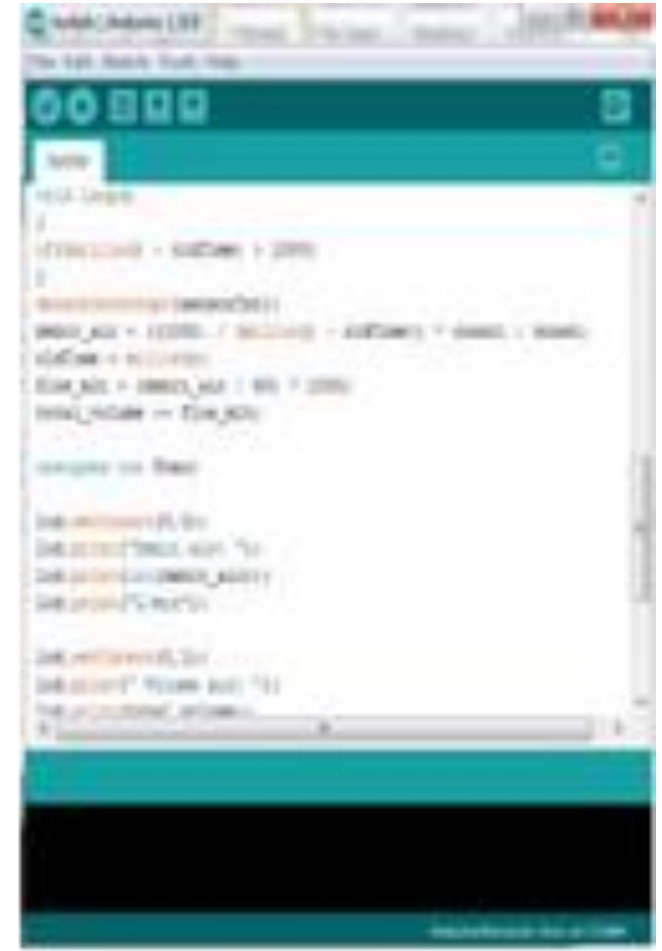

Figure 2.6 Display of the Arduino Program

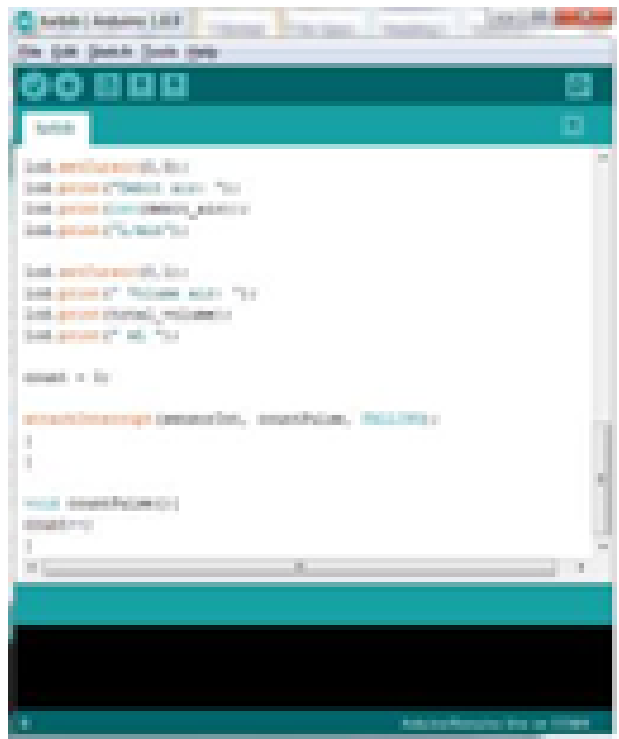

Figure 2.6 Display of the Arduino Program

\subsection{Discussion}

In "Design of Hydroelectric Generator for Street Lighting (Pju) with Water Level Control Sensor Based on Arduino Uno". This tool uses a water level sensor with an LCD output via Arduino which aims to drive the water turbine generator. This tool can be used by the community at night for lighting so as to minimize crime. 
The purpose of designing and testing this tool is to determine the function of the water level sensor on the water level. This tool consists of a number of components, namely the water container as a reservoir, the microcontroller as the "brain" which will determine when the water pump will turn on, the LCD as the output.

In this research, the calculated input and output values from the trials that have been done have been generated. The trial results have been presented in table 1 to table 2.

Table 1. Calculation of Vin and Vout from MHP in June 2020

\begin{tabular}{|c|c|c|c|}
\hline No. & WAKTU & Vin & Vout \\
\hline 1 & 00.00 & 3,5Volt & 2,6 Volt \\
\hline 2 & 01.00 & 3,5 Volt & 2,6 Volt \\
\hline 3 & 02.00 & 3,5Volt & 2,6 Volt \\
\hline 4 & 03.00 & 3,5Volt & 2,6 Volt \\
\hline 5 & 04.00 & 3,5Volt & 2,6Volt \\
\hline 6 & 05.00 & 3,5Volt & 2,6 Volt \\
\hline 7 & 06.00 & 3,5Volt & 2,6 Volt \\
\hline 8 & 07.00 & 3,5 Volt & 2,6 Volt \\
\hline 9 & 08.00 & 3,3Volt & 2,4 Volt \\
\hline 10 & 09.00 & 3,3Volt & 2,4 Volt \\
\hline 11 & 10.00 & 3,3Volt & 2,4 Volt \\
\hline 12 & 11.00 & 2,6Volt & $2,2 \mathrm{Volt}$ \\
\hline 13 & 12.00 & 2,6 Volt & 2,2 Volt \\
\hline 14 & 13.00 & 2,6 Volt & 2,2Volt \\
\hline 15 & 14.00 & 2,6 Volt & 2,2Volt \\
\hline 16 & 15.00 & 2,6 Volt & 2,2Volt \\
\hline 17 & 16.00 & 2,6 Volt & 2,2Volt \\
\hline 18 & 17.00 & 2,6 Volt & 2,2Volt \\
\hline 19 & 18.00 & 2,6 Volt & 2,2 Volt \\
\hline 20 & 19.00 & 3,3Volt & 2,4 Volt \\
\hline 21 & 20.00 & 3,3Volt & 2,4 Volt \\
\hline 22 & 21.00 & 3,3Volt & 2,4 Volt \\
\hline 23 & 22.00 & 3,5 Volt & 2,6 Volt \\
\hline 24 & 23.00 & 3,5Volt & 2,6Volt \\
\hline
\end{tabular}

Table 2. Calculation of Vin and Vout from MHP in July 2020

\begin{tabular}{|c|c|c|c|}
\hline No. & WAKTU & Vin & Vout \\
\hline 1 & 00.00 & 3,7 Volt & 2,8 Volt \\
\hline 2 & 01.00 & 3,7 Volt & $2,8 \mathrm{Volt}$ \\
\hline 3 & 02.00 & 3,7 Volt & 2,8Volt \\
\hline 4 & 03.00 & 3,7 Volt & 2,8 Volt \\
\hline 5 & 04.00 & 3,7 Volt & $2,8 \mathrm{Volt}$ \\
\hline 6 & 05.00 & 3,7 Volt & 2,8 Volt \\
\hline 7 & 06.00 & 3,7 Volt & 2,8Volt \\
\hline 8 & 07.00 & 3,7 Volt & 2,8 Volt \\
\hline 9 & 08.00 & 3,5Volt & 2,6 Volt \\
\hline 10 & 09.00 & 3,5Volt & 2,6Volt \\
\hline 11 & 10.00 & 3,5Volt & 2,6Volt \\
\hline 12 & 11.00 & $2,8 \mathrm{Volt}$ & 2,4 Volt \\
\hline 13 & 12.00 & $2,8 \mathrm{Volt}$ & 2,4 Volt \\
\hline 14 & 13.00 & $2,8 \mathrm{Volt}$ & 2,4 Volt \\
\hline 15 & 14.00 & $2,8 \mathrm{Volt}$ & 2,4 Volt \\
\hline 16 & 15.00 & $2,8 \mathrm{Volt}$ & 2,4 Volt \\
\hline 17 & 16.00 & $2,8 \mathrm{Volt}$ & 2,4 Volt \\
\hline 18 & 17.00 & $2,8 \mathrm{Volt}$ & 2,4 Volt \\
\hline 19 & 18.00 & $2,8 \mathrm{Volt}$ & 2,4 Volt \\
\hline 20 & 19.00 & 3,5Volt & 2,6Volt \\
\hline 21 & 20.00 & 3,5Volt & 2,6Volt \\
\hline 22 & 21.00 & 3,5Volt & 2,6Volt \\
\hline 23 & 22.00 & 3,7 Volt & 2,8Volt \\
\hline 24 & 23.00 & 3,7 Volt & 2,8 Volt \\
\hline
\end{tabular}


Table 3.Water Volume and Discharge in June 2020

\begin{tabular}{|c|c|c|c|}
\hline No. & WAKTU & VOLUME & DEBIT \\
\hline 1 & 00.00 & $240 / \mathrm{s}$ & 4 liter/menit \\
\hline 2 & 01.00 & $240 / \mathrm{s}$ & 4 liter/menit \\
\hline 3 & 02.00 & $240 / \mathrm{s}$ & 4 liter/menit \\
\hline 4 & 03.00 & $240 / \mathrm{s}$ & 4 liter/menit \\
\hline 5 & 04.00 & $240 / s$ & 4 liter/menit \\
\hline 6 & 05.00 & $240 / \mathrm{s}$ & 4 liter/menit \\
\hline 7 & 06.00 & $240 / \mathrm{s}$ & 4 liter/menit \\
\hline 8 & 07.00 & $240 / \mathrm{s}$ & 4 liter/menit \\
\hline 9 & 08.00 & $180 / \mathrm{s}$ & 3 liter/menit \\
\hline 10 & 09.00 & $180 / \mathrm{s}$ & 3 liter/menit \\
\hline 11 & 10.00 & $180 / \mathrm{s}$ & 3 liter/menit \\
\hline 12 & 11.00 & $120 / \mathrm{s}$ & 2 liter/menit \\
\hline 13 & 12.00 & $120 / \mathrm{s}$ & 2 liter/menit \\
\hline 14 & 13.00 & $120 / \mathrm{s}$ & 2 liter/menit \\
\hline 15 & 14.00 & $120 / \mathrm{s}$ & 2 liter/menit \\
\hline 16 & 15.00 & $120 / \mathrm{s}$ & 2 liter/menit \\
\hline 17 & 16.00 & $120 / \mathrm{s}$ & 2 liter/menit \\
\hline 18 & 17.00 & $120 / \mathrm{s}$ & 2 liter/menit \\
\hline 19 & 18.00 & $120 / \mathrm{s}$ & 2 liter/menit \\
\hline 20 & 19.00 & $180 / \mathrm{s}$ & 3 liter/menit \\
\hline 21 & 20.00 & $180 / \mathrm{s}$ & 3 liter/menit \\
\hline 22 & 21.00 & $180 / \mathrm{s}$ & 3 liter/menit \\
\hline 23 & 22.00 & $240 / \mathrm{s}$ & 4 liter/menit \\
\hline 24 & 23.00 & $240 / \mathrm{s}$ & 4 liter/menit \\
\hline
\end{tabular}

Table 4. Water Volume and Discharge in July 2020

\begin{tabular}{|c|c|c|c|}
\hline No. & WAKTU & VOLUME & DEBIT \\
\hline 1 & 00.00 & $300 / \mathrm{s}$ & 5 liter/menit \\
\hline 2 & 01.00 & $300 / \mathrm{s}$ & 5 liter/menit \\
\hline 3 & 02.00 & $300 / \mathrm{s}$ & 5 liter/menit \\
\hline 4 & 03.00 & $300 / \mathrm{s}$ & 5 liter/menit \\
\hline 5 & 04.00 & $300 / \mathrm{s}$ & 5 liter/menit \\
\hline 6 & 05.00 & $300 / \mathrm{s}$ & 5 liter/menit \\
\hline 7 & 06.00 & $300 / \mathrm{s}$ & 5 liter/menit \\
\hline 8 & 07.00 & $300 / \mathrm{s}$ & 5 liter/menit \\
\hline 9 & 08.00 & $240 / s$ & 4 liter/menit \\
\hline 10 & 09.00 & $240 / s$ & 4 liter/menit \\
\hline 11 & 10.00 & $240 / \mathrm{s}$ & 4 liter/menit \\
\hline 12 & 11.00 & $180 / \mathrm{s}$ & 3 liter/menit \\
\hline 13 & 12.00 & $180 / \mathrm{s}$ & 3 liter/menit \\
\hline 14 & 13.00 & $180 / \mathrm{s}$ & 3 liter/menit \\
\hline 15 & 14.00 & $180 / \mathrm{s}$ & 3 liter/menit \\
\hline 16 & 15.00 & $180 / \mathrm{s}$ & 3 liter/menit \\
\hline 17 & 16.00 & $180 / \mathrm{s}$ & 3 liter/menit \\
\hline 18 & 17.00 & $180 / \mathrm{s}$ & 3 liter/menit \\
\hline 19 & 18.00 & $180 / \mathrm{s}$ & 3 liter/menit \\
\hline 20 & 19.00 & $240 / s$ & 4 liter/menit \\
\hline 21 & 20.00 & $240 / \mathrm{s}$ & 4 liter/menit \\
\hline 22 & 21.00 & $240 / s$ & 4 liter/menit \\
\hline 23 & 22.00 & $300 / \mathrm{s}$ & 5 liter/menit \\
\hline 24 & 23.00 & $300 / \mathrm{s}$ & 5 liter/menit \\
\hline
\end{tabular}

Table 5. Power Calculation for June 2020

\begin{tabular}{lcr}
\hline No. & WAKTU & DAYA \\
1 & 00.00 & 101.6 Watt \\
2 & 01.00 & 101.6 Watt \\
3 & 02.00 & 101.6 Watt \\
4 & 03.00 & 101.6 Watt \\
5 & 04.00 & 101.6 Watt \\
6 & 05.00 & 101.6 Watt \\
7 & 06.00 & 101.6 Watt \\
8 & 07.00 & 101.6 Watt \\
9 & 08.00 & 71.2 Watt \\
10 & 09.00 & 71.2 Watt
\end{tabular}




\begin{tabular}{ccc}
11 & 10.00 & $\mathbf{7 1 . 2}$ Watt \\
12 & 11.00 & $\mathbf{5 6 . 0 2}$ Watt \\
13 & 12.00 & $\mathbf{5 6 . 0 2}$ Watt \\
14 & 13.00 & $\mathbf{5 6 . 0 2}$ Watt \\
15 & 14.00 & $\mathbf{5 6 . 0 2}$ Watt \\
16 & 15.00 & 56.02 Watt \\
17 & 16.00 & $\mathbf{5 6 . 0 2}$ Watt \\
18 & 17.00 & 56.02 Watt \\
19 & 18.00 & $\mathbf{5 6 . 0 2}$ Watt \\
20 & 19.00 & 71.2 Watt \\
21 & 20.00 & 71.2 Watt \\
22 & 21.00 & 71.2 Watt \\
23 & 22.00 & 101.6 Watt \\
24 & 23.00 & 101.6 Watt \\
\hline
\end{tabular}

Table 6. Power Calculation July 2020

\begin{tabular}{lll}
\hline No. & WAKTU & DAYA \\
1 & 00.00 & 121.6 Watt \\
2 & 01.00 & 121.6 Watt \\
3 & 02.00 & 121.6 Watt \\
4 & 03.00 & 121.6 Watt \\
5 & 04.00 & 121.6 Watt \\
6 & 05.00 & 121.6 Watt \\
7 & 06.00 & 121.6 Watt \\
8 & 07.00 & 121.6 Watt \\
9 & 08.00 & 91.2 Watt \\
10 & 09.00 & 91.2 Watt \\
11 & 10.00 & 91.2 Watt \\
12 & 11.00 & 76.02 Watt \\
13 & 12.00 & 76.02 Watt \\
14 & 13.00 & 76.02 Watt \\
15 & 14.00 & 76.02 Watt \\
16 & 15.00 & 76.02 Watt \\
17 & 16.00 & 76.02 Watt \\
18 & 17.00 & 76.02 Watt \\
19 & 18.00 & 76.02 Watt \\
20 & 19.00 & 91.2 Watt \\
21 & 20.00 & 91.2 Watt \\
22 & 21.00 & 91.2 Watt \\
23 & 22.00 & 121.6 Watt \\
24 & 23.00 & 121.6 Watt \\
\hline
\end{tabular}

\section{CONCLUSION}

\subsection{Conclusion}

Of all the stages that have been carried out in the preparation of this Final Project, starting from literature studies, design and manufacture to testing, it can be concluded that:

a. Test results with a water discharge of $5 \mathrm{~L}$ / minute and a flow volume of 0.3 / s generated in 1 day

b. The results of the Input and Output Voltage Test, with an average value of Vin 3.35 Volt and Vout 2.61 Volt produced on 1 day

c. From the impulse turbine test, it can produce generator power with an average value of 98.8 Watts in 1 day.

\subsection{Suggestion}

Due to the limited time in working on this tool, the suggestions that the author can give to be able to develop this research are in terms of the sensors used, for further research sensors that can be used can use larger sensors, making them more accurate and faster. And can be applied to the design so that it can be used in the community.

\section{ACKNOWLEDGMENTS}

The author needs to convey gratitude and appreciation to various parties who have provided assistance in the form of guidance, direction, advice, support and convenience from the beginning to the end of the preparation of the Final Project. Do not forget to say our thanks to: 
1. Both parents and the whole family who have given their prayers and affection.

2. Mrs. Yunia Dwie Nurcahyanie, ST., MT. as Dean of the Faculty of Engineering, Universitas PGRI Adi Buana Surabaya.

3. Mr. Akbar Sujiwa, SSi, MSi as the Head of the Electrical Engineering Study Program.

4. All Lecturers and Staff in the Electrical Engineering Study Program, Faculty of Engineering.

5. Friends (Loss Ga Fussy) of Electrical Engineering Study Program in the same generation for their solidarity.

\section{REFERENCE}

[1] Agus. R, 2007. Pembangkit Listrik Tenaga Mirko Hidro (PLTMH) : Jurnal Vokasi. Politeknik Negeri Pontianak. Kalimantan Barat.

[2] Anderson, J., 2011. Design and Manufacture of a Cross-Flow Helical Tidal Turbine : Capstone Project Report. University of Washington.Amerika Serikat.

[3] Date, A., 2014. Experimental Performance of a Rotating Two-Phase Reaction Turbine : Applied hermal Engineering. Vol 76. RMIT University. Australia.

[4] Gorlov A.M, 1998. Turbine With a Twist : Journal Macro-Engineering and The Earth World Project for Year 2000 and Beyond. Northeastern University.Boston, MA.
[5] Fox,R.W,Mc Donald,A.T, Pritchard, P.J., 2004. Introduction to Fluid Mechanics.United State of America. John Wiley and Sons, Inc.

[6] Https://www.scribd.com/document/325136022/Makalah-Generator-AC-DanDC

[7] Kurniawan, I. 2014. Kajian Eksperimental dan Numerikal Turbin Air Helikal

[8] Rochman, Sagita, and Akbar Sujiwa. "Peningkatan Daya Output Generator Listrik Tipe Afpmg Pada Putaran Rendah Menggunakan 3 Rotor Dan 2 Stator."

[9] Sentanu, H., 2013. Pembangkit Listrik Tenaga Mikrohidro. Dapat diunduh di http://mts.ft.ugm.ac.id/download/3.

Pemeliharaan dan_Pengoperasian PLTMH AHB Sentanu.pdf. Diunduh pada tanggal 9 Maret 2017

[10] Sihombing, E., 2009. Pengujian Sudu Lengkung Prototipe Turbin Air Terapung pada Aliran Sungai : Jurnal Teknik Mesin. Universitas Sumatera Utara.Sumatera Utara.

[11] Sujiwa, Akbar, and Sagita Rochman. "Pengembangan Sistem Kontrol Serta Monitoring Suhu dan Volume Air Berbasis Web Pada Perangkat Desalinasi Air Laut." SNHRP (2019): 19. 